\title{
FINANCIAL EVALUATION OF SOME AGRICULTURAL INITIATIVE PROJECTS IN IRAQ
}

D. S. Barbaz

Lecturer
A. D. K. AL-Hiyali

Professor

Dept. of Agric. Economics /Coll. of Agric. /University of Baghdad

\section{ABSTRACT} dhurghambarbaz@gmail.com

adk_1966@yahoo.com

This research aims to identify the financial feasibility of some agricultural activities benefiting from the initiative's lending funds, as well as to show the impact of the agricultural initiative on those projects in terms of raising the financial feasibility of their establishment, in the light of the results of the evaluation criteria addressed in the research. Between the years 2009-2011, the financial accounts of the projects were monitored until 2018 to obtain cash flows for the studied projects. Some projects, despite their high investment costs, have been shown to be able to recover the funds invested in a relatively short period of time, and feed plants and similar projects have the potential to recover their costs in a relatively short period. The index of profitability index also showed that most of the productive activities generate a return that exceeds the dinar invested in close proportions, and loans have a significant role in raising the efficiency and profitability of some projects that the state wishes to revitalize despite the non-profit projects in the natural conditions. The NPV values calculated using a discount factor of $10 \%$ in the studied projects were positive, indicating the feasibility of investing in these projects, with the exception of the dairy cattle breeding project, which has a net present value of about $\mathbf{- 8 , 7 3 0 , 9 0 5}$ dinars. Results came from the discounted profitability index standard. The project also achieved the largest value of the profitability index, as the value of the index reached about 2.408 . The research recommended that the need to use lending funds for the agricultural initiative as a tool to raise the efficiency and feasibility of agricultural projects that would contribute to the process of agricultural development in Iraq.

Key word: cash flow, internal rate of return, discounted profitability index.

*Part of Ph.D. dissertation of the $\mathbf{1}^{\text {st }}$ author.

برباز وكسار مجلة العوم الزراعية العراقية -1633-1623:51:2020 (6) مئ التقييم المالي لبعض مشروعات المبادرة الزراعية في العراق

$$
\text { ضرغام سلمان برباز }
$$

قسم الاقتصاد الزراعي / كلية علوم الهندسة الزراعية / جامعة بغداد

يهدف البحث التعرف الى الجدوى المالية لبعض الانشطة الزراعية المستفيدة من صناديق اقراض المبادرة الزراعية ، فضلا عن بيان اثر المبادرة الزراعية

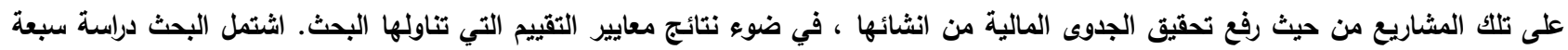
مشروعات تأسست ما بين الاعوام 2009-2011 ، وقد تم متابعة الحسابات المالية للمشروعات لغاية عام 2018 للحصول على على التدفقات النقاية للمشروعات المدروسة. وقد تبين تميز بعض المشاريع على الرغم من تكاليفها الاستثمارية العالية بقدراتها على استرداد الاموال المستثمرة فيها خلال

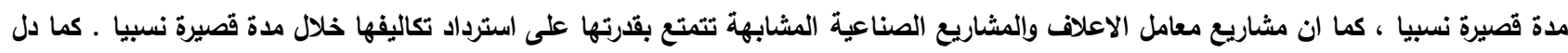
معيار دليل الريحية ان اغلب الانثطة الانتاجية تدر عائد يفوق الدينار المستثمر فيها بنسب متقارية، وكان للقروض دوراً كبيراً في رفع كفاعة وربحية

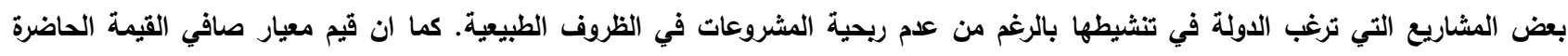

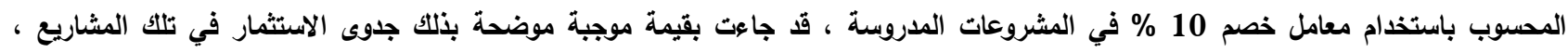
باستثاء مشروع تربية ابقار الحليب الذي بلغ قيمة معيار صافي القيمة الحاضرة نحو 8,730,905- دينار وهي قيمة سالبة تلدعم ما جاء من نتائج بحسب معيار دليل الريحية المخصوم ـ كما حقق مشروع احواض الاسماك اكبر قيمة لمؤثر الريحية، اذ بلغت قيمة المؤثر نحو البحث بضرورة استخدام الصناديق الاقراضية للمبادرة الزراعية كأداة لرفع كفاعة وجدوى المشروعات الزراعية والتي من شأنها ان تشهم في عملية التنمية الزراعية في العراق. الكلمات المفتاحية: التدفقات النقلية، معدل العائد الداخلي، صافي القيمة الحالية، دليل الريحية المخصوم. 


\section{INTRODUCTION}

The agricultural system is an integrated set of activities performed by farmers in the field under cultivation conditions to maximize production and net income on a sustainable basis through types of agricultural systems and evaluate these possibilities to increase farm income through resource allocation (11). One of the objectives of economic development is to eradicate poverty and to make optimal use of production resources. Living for current and future generations (14). The ability of our planet to produce enough food for the population of the globe based on agriculture was the subject of discussion by many researchers who concluded that irrigated agriculture covers about 275 million hectares globally and produces about $40 \%$ of food crops. The level of productivity has improved only slightly, and this increase has been accompanied by high costs and this refers to the reliance on old methods on the one hand and not to use scientific management on the other (10). Economic efficiency is a term commonly used in microeconomics and refers to the production of a unit that is economically effective when it is produced at the lowest possible cost. There are three sufficient conditions to achieve them, first: achieving marginal benefit for all consumers; second: that all producers work on the same marginal cost and finally that the profit margin for each product is equal to the marginal cost of each supplier (15). We conclude that the concept of economic efficiency is a relative concept. Agricultural investment in achieving efficiency and encouraging returns on investment, as well as the feasibility of investing in those projects through some financial evaluation criteria, to detect glitches to avoid them and to identify the strengths to strengthen them. This research aims to assess financially some of the investment projects financed by the lending funds of the Agricultural Initiative in Iraq.

\section{MATERIALS AND METHODS}

The research requirements were met from the data needed based on a sample questionnaire, which included a feed lab project, meat broiler project, table egg production project, poultry hatchery project, protected agricultural project, fish ponds project and milk cows project. The data of the studied projects were covered from 2009 to 2018 to obtain cash inflows and outflows of the studied projects, and the projects borrowed from the Agricultural Investment Fund were targeted. Projects will be assessed financially using a set of project evaluation criteria.

\section{Theoretical framework}

The level of the performance appraisal system reflects the maturity of society in facilitating its affairs and represents the tool by which we recognize the current reality in preparation for its development (22). Assessing projects is increasingly important as the state tends to reduce the role of the public sector and the role of the private sector and to optimize the use of available resources by channeling these resources to the best available uses or socalled rational use. Economic efficiency is defined as the use of sources of wealth in such a way as to achieve one of two things: first, achieving greater production at the same past production costs; and second, the same production at lower costs of production (17). It also defines the maximization of profit within the production unit using the ideal elements of production. The process of studying the efficiency of performance in the economic project is closely related to the evaluation process and the feasibility of the project, because the tagged objectives of the project, which are expected to be achieved in the short and long term through economic activities have been developed and determined based on the criteria and bases adopted in the evaluation of projects (1). All this makes the process of studying and evaluating farms a comprehensive and integrated in nature, and therefore, determining the appropriate criteria for agricultural activities is one of the most important bases in the process of assessing the efficiency of agricultural activity in those projects. The evaluation process takes place in all economic activities, whether agricultural, industrial or service activities. There is no fundamental difference in the evaluation of these activities, but the difference in how to choose the appropriate criteria for each activity (18). The research has adopted a set of evaluation criteria.

1- Pay-back period (PBP): the period required to recover the capital invested in the 
project (2) the length of time in which the revenue can pay the amounts invested in the farm and uses the law below to calculate (19):

$$
\text { PBP }=\frac{\text { Capital invested }}{\text { Annual profit }}
$$

2- Simple rate of return (SRR): This criterion is sometimes called the accounting rate of return since it depends on predicting what the results of the profit and loss accounts in the accounting entries will be and calculated using the law (3):

$$
\text { SRR }=\frac{\text { Annual profit }}{\text { Capital invested }} \times 100
$$

3- Benefit-cost ratio (discounted profitability index): It is outside of dividing the present value of cash inflows of the project on the present value of cash outflows from the project (21). It is desirable to follow one way in the calculation of this standard when we use the basis for the evaluation of projects in the country so as to minimize the misleading projects in the order of selection opportunities. For the purpose of trade-offs between alternatives are given priority to those projects that achieve the highest rate in the economic evaluation process, and can be expressed mathematically this standard as follows (8):

As:

$$
B / C \text { ratio }=\frac{\sum_{t=1}^{n} \frac{\mathrm{Bn}}{(1+\mathrm{r})^{\mathrm{n}}}}{\sum_{t=1}^{n} \frac{\mathrm{Cn}}{(1+\mathrm{r})^{\mathrm{n}}}}
$$

$\mathrm{B} / \mathrm{C}$ ratio: benefit / cost ratio., $\mathrm{B}_{\mathrm{n}}$ : inflows., $\mathrm{C}_{\mathrm{n}}$ : outflows.,N: Age of Economic Project.,R: interest rate

This equation represents the first criterion for evaluating the economic feasibility table and the general rule is to accept projects that when the benefits are divided by the present value of the costs by the present value, the result is one and more true in the case of one project, either in the case of several projects, the project that achieves the highest rate is the most feasible. Economic aspect (4).

4- Net present value (NPV): Present value is the discounted value of future cash flows received (24). Net present value is a method of calculating discounted cash flow (26) .Net present value is defined as a means of calculating the present value of cash inflows and outflows of an investment. The net present value takes into account the time value of money (5). This concept overcomes the difficulty of trying to reconcile the costs and returns that arise during different periods of time by making all amounts equal, converting them to a common basis or a present common value so that all financial costs are equal to future financial returns (20) by using a discount factor to discount Cash inflows to their present value, after which the present value of all cash inflows is compared with outflows (27). This is expressed mathematically as follows (12):

$$
N P V=\sum_{t=1}^{n} \frac{\mathrm{Bn}}{(1+\mathrm{r})^{\mathrm{n}}}-\sum_{t=1}^{n} \frac{\mathrm{Cn}}{(1+\mathrm{r})^{\mathrm{n}}}
$$

As:NPV: Net present value., $B_{n}$ : inflows., $C_{n}$ : outflows.,N: Age of economic project.,R: Interest rate.

Cash flow and discount rate are key factors in the NPV calculation (7). Whereas the NPV standard includes an assessment of the present value of cash flows represented by the expected profit dividend using a discount rate that takes into account the investment risk, the value obtained is compared to the initial cost (23). In general, the investment project is accepted if it is NPV $>0$, and rejected if it is NPV $<0$. The investment project covers its economic costs only if $\mathrm{NPV}=0$. One disadvantage of using this is that if the funds invested differ from one project to another, the comparison does not produce results with meaningful meaning (25). Therefore, in order to overcome the weaknesses of this standard has been made some amendments to it, instead of dealing with the total return achieved, was adopted and dealt with the monetary unit invested revenue, which is the common denominator of capital invested in various projects .In order to address this issue in order to arrive at a sound and accurate trade-off, this has led to the adoption of a new standard, the Index of adjustment Present value or the Profitability Index (PI), which can be expressed in the following form

$$
I P=\frac{N P V}{\text { Inevstment costs }}
$$

5- Internal Rate of Return :Internal Rate of Return (IRR) is the projected rate of return on an investment, and is therefore defined as a discount rate that is equal to the present value of the expected cash flows with the investment 
expenses (27). Thus, the IRR is only a discount rate that makes the net present value equal to zero (8). The NPV and IRR criteria generally lead to the same decision of acceptance or rejection with respect to investment choice (26). However, there are instances where the application of these criteria leads to conflicting results. The reasons for this discrepancy are the different assumptions of the NPV and IRR regarding the rate at which the cash flows are reinvested, as the two methods assume that such funds invest at a different rate of return (20). Net present value implies that the rate at which cash flows can be reinvested is the rate of return required, while the internal rate of return indicates that the investor has an opportunity to invest at the same internal rate of return. The internal rate of return is defined as the discount rate that makes the NPV reach zero. It is also known as a discount rate that equals the present value of cash flows over the life of an investment with the value of the initial investment. The IRR value of an investment can be calculated (assuming that the initial investment value is achieved in year 0 by equating NPV with zero as follows (8):

$$
N P V=\sum_{t=1}^{n} \frac{\mathrm{Bn}}{(1+\mathrm{r} *)^{\mathrm{n}}}-\sum_{t=1}^{n} \frac{\mathrm{Cn}}{(1+\mathrm{r} *)^{\mathrm{n}}}=0
$$

As:NPV: Net Present Value., $\mathrm{B}_{\mathrm{n}}$ : inflows.investment., $\mathrm{C}_{\mathrm{n}}$ : outflows.,N: Age of Economic Project..R*: Internal Rate of Return. Next, the value of $r *$ must be found that meets the following condition $(\mathrm{NPV}=\mathrm{O})$, as $\mathrm{r} *$ will represent the IRR of the proposed investment. This rate will represent the profitability of the capital invested in the project throughout its useful life, that is, during the period in which it resides.

\section{RESULTS AND DISCUSSION}

The success of the evaluation process depends on the selection of appropriate indicators and criteria that are compatible with the nature of the project to be evaluated. To determine the level of technical and economic efficiency enjoyed by these projects, especially after the flows of the studied projects were obtained, the results of indicators and criteria were extracted financial evaluation using a discount factor of $10 \%$, as studies show Previously, the discount rate for agricultural projects in most developing countries ranges between $8 \%$ and
$15 \%$. There is no certain knowledge of the real opportunity costs of capital. To calculate the payback period more precisely by estimating the present value accumulations of total benefits minus the associated costs and comparing them with the present value of the investment costs of the project. By comparing the accumulated and discounted net cash flows with the $10 \%$ discount factor achieved by the projects studied during their useful lives with their investment costs, as shows in Table 1, there is a variation in the value of the recovery period criterion for agricultural projects in the recovery of the funds invested according to the method used in The calculation of the standard, as the calculation of the standard by way of net annual flow, gives an inaccurate indication in the ability of various projects to recover the invested capital and thus the loans granted to these projects. We note that the payback period ranges between one and three years for different projects in different investment volume, as the highest undiscounted payback period was recorded in the table egg production project which amounted to about 4.009 years, the project recovered the capital within four years, in the presence of loans granted The impact of the existence of loans in the financing of projects does not appear on the undiscounted payback period. This effect has included all agricultural projects regardless of the size or the amount of the loan granted, because loans and loan installments in the light of the lack of interest rate become book restrictions cancel one of them the other. The results obtained are different from the calculation of the redemption period by accumulating cash flow, as it appears that the table egg production project recovers capital in the sixth year, and although this calculation method does not take into account the time value of money, but the results came close to the calculation of the redemption period. The project has recovered the invested funds within six years and nine months, and has shown the impact of financing the project with loans as the payback period for the table egg production project decreased to about 6.02 years, the project recovers the invested capital at the end of the sixth year. The volume of investment in such projects constituted about $35 \%$ of the total investment 
in the projects studied, the highest percentage recorded in the projects studied, while the milk cattle breeding project recorded the highest recovery period when calculated by discounted flows, despite the decrease in investment costs, which constitute about $4 \%$ The value of the standard was about 10.28 , which means that the project recovered the money invested in it within ten years and three months, which is a relatively long period. This may be due to the high operating costs of such projects, especially the costs of milk production compared to the lowest. The loan contributed to reducing the payback period to about eight and a half years if the value of the criterion is about 8.48, while the calculation of the criterion of the undiscounted payback period showed that the project recovered its funds within five years and six months. Calculating the payback period on the basis of discounted flows, due to the impact of the time value of money, which may give a false picture of the period in which the project recovered its funds.

Table 1. Results of the pay-back period criterion

\begin{tabular}{|lcccc|}
\hline & $\begin{array}{c}\text { Discounte } \\
\text { d P. B P. } \\
\text { (Loan } \\
\text { financing) }\end{array}$ & $\begin{array}{c}\text { Common } \\
\text { Pay-Back } \\
\text { period } \\
\text { (Loan } \\
\text { financing) }\end{array}$ & $\begin{array}{c}\text { Discounte } \\
\text { d Pay-Back } \\
\text { period } \\
\text { (Self - } \\
\text { financing) }\end{array}$ & $\begin{array}{c}\text { Common } \\
\text { Pay-Back } \\
\text { period } \\
\text { (Self - } \\
\text { financing) }\end{array}$ \\
\hline Feed Factory & 1.630 & 1.195 & 1.860 & 1.195 \\
Poultry hatchery & 3.501 & 2.527 & 3.929 & 2.527 \\
Production of broiler chickens & 4.231 & 3.134 & 4.873 & 3.134 \\
Production of chicken eggs & 6.024 & 4.007 & 6.800 & 4.007 \\
Farm greenhouses & 4.231 & 2.815 & 4.507 & 2.815 \\
Fish ponds & 2.083 & 1.415 & 2.347 & 1.415 \\
Breeding of milk cows & $\mathbf{8 . 4 7 2}$ & 5.492 & 10.281 & 5.492 \\
\hline
\end{tabular}

Source: Prepared by the researcher based on the questionnaire data.

As for the results of the accounting rate of return because of the shortcomings of the calculation method of this standard in its dependence on net annual profit and not on net cash flow, project management is concerned primarily with cash flow and not profit, because in order to achieve additional profits must obtain the cash available for reinvestment, and of course not There is a guarantee that the realized profits are available in the form of cash available. The available cash may be less or more than the realized profits depending on the selling policies, collection policy, repayment policies, taxes and extinction. Cash flows instead of net profit can be used to calculate a simple rate of return.
The loan has reduced the payback period to about eight and a half years, we conclude that the agricultural initiative contributed to reduce Pay-Back period. The feed plant project achieved the lowest discounted recovery period in the studied projects, which amounted to about 1.860 , which decreased to about 1.63 with the loan. The effect of calculating the standard method did not appear significantly in this project. This is an indication that the specificity of some industrial projects and activities is not affected many measurement way. From the above, we can see that the method used in calculating the standard of the payback period can produce different results, and neglecting the time value of money leads to inaccurate results. Some projects, despite their high investment costs, were characterized by their ability to recover funds invested in a relatively short period of time, and feed plants and similar projects have the ability to recover their costs in a relatively short period.
In order to be accurate, the simple rate of return was calculated in two ways Table 2 . The results showed that using net profit, the collection of projects achieved values of the criterion exceeding the prevailing interest rates in the markets, which is an indication of the profitability of the studied projects and economic feasibility. The only project for the ponds was $74 \%$ and $54 \%$ respectively, while the standard values increased to about $83 \%$ and $70 \%$ respectively for the two projects using the net cash flow method. This is the lowest value of the simple rate of return calculated by the method of net profit in the dairy cattle breeding project, while the value of the standard net cash flow for the same 
project about $18 \%$, that is, the ruminant breeding project has achieved returns above the prevailing interest rates and is a profitable projects that It is efficient and economically feasible, and if the results of the simple rate of return are compared with the results of the other criteria, the shortcomings of the simple rate of return will be shown in judging the feasibility and profitability of some projects. That is, there is no correlation between the results of the standard payback period with this standard. We can conclude from the above that reliance on the simple rate of return, however different the calculation method may lead to misleading and inaccurate results, and the dependence on profits earned instead of cash flows that can be reinvested leads to judgment and the issuance of shaded investment decisions.

\section{Table 2. Results of the simple rate of return criterion}

\begin{tabular}{|lcc|}
\hline Projects & $\begin{array}{c}\text { S.R.R in net cash } \\
\text { flow method }\end{array}$ & $\begin{array}{c}\text { S.R.R in net profit } \\
\text { method }\end{array}$ \\
\hline Feed Factory & $\mathbf{8 3 . 7 \%}$ & $\mathbf{7 4 . 6 \%}$ \\
Poultry hatchery & $\mathbf{3 9 . 6 \%}$ & $\mathbf{3 1 . 9 \%}$ \\
Production of broiler chickens & $\mathbf{3 1 . 9 \%}$ & $\mathbf{2 4 . 0 \%}$ \\
Production of chicken eggs & $\mathbf{2 5 . 0 \%}$ & $\mathbf{1 6 . 9 \%}$ \\
Farm greenhouses & $\mathbf{3 5 . 5 \%}$ & $\mathbf{2 9 . 7 \%}$ \\
Fish ponds & $\mathbf{7 0 . 7 \%}$ & $\mathbf{5 4 . 7 \%}$ \\
Breeding of milk cows & $\mathbf{1 8 . 2 \%}$ & $\mathbf{1 2 . 3 \%}$ \\
\hline
\end{tabular}

Source: Prepared by the researcher based on the questionnaire data

The results in table 3, shows that the greenhouses project achieved the highest value of the discounted and undiscounted profitability index, as the value of the undiscounted standard was about 1.445, meaning that every dinar spent in the project made a profit of 445 fils, while it dropped to about 413 fils Per dinar investor when using the discounted profitability index criterion and here we note a slight difference in the value of the criterion caused by the time value of money, and this is perhaps the most important reasons for the high return of the dinar in such projects compared to the projects studied is the low investment costs, which constitute only 7\% Total investment costs The loan has contributed to raising the profitability of the invested dinar, as the discounted standard amounted to 1.298 , an increase of $1.3 \%$, although the ratio of loan to investment costs in the project amounted to about $38 \%$, which is the lowest percentage recorded in the studied projects. The dairy cattle breeding project has achieved losses for the dinar invested, where the discounted criterion value is less than one, the value of the index of profitability was about 0.988 , every dinar invested in ruminant breeding projects has achieved a loss of 12 fils, and perhaps the most important reasons The fact that milk cows are one of the unprofitable projects is due to the low milk production rates in these projects, and milk productivity per cow is often reduced compared to other countries. This undisclosed profitability index showed that the project makes a profit of 278 fils per dinar invested. The value of the standard 1.278 is the second year this shows the lack of the undiscounted profitability index compared to the discounted profitability index in judging the profitability of the project. The provision of loans to such projects contributes to increase their financial capacity and enhance the profitability of projects, if the plans and strategies Aiming to increase milk production locally to support local industries and face imported products in order to fill the food gap of some agricultural products, we note that the project of raising milk cows due to the loan has become a profit of 67 fils per dinar invested, although the loan ratio The forbidden project accounted for only about $4 \%$ of the total loans granted to the projects, as the loan was able to increase the yield of the dinar investor by $8 \%$, the highest percentage of registered. This has been the advantage of broiler meat projects at the level of poultry sector projects if the dinar invested a profit of about 167 fils decreased after the time value of money to about 81 fils, while the loan contributed to raise the profitability of the dinar invested to about 113 dinars per dinar investor superior to table eggs production projects, which amounted to a discounted profitability index of 1.004 , while the loan 
contributed to raise the profitability of the dinar invested to about 22 fils per dinar invested. We can see from the above that most of the productive activities generate a return exceeding the dinar invested in close proportions, which is logical results in the light of competition in the markets between different projects, as loans have a significant role in raising the efficiency and profitability of some projects that the state wishes to activate despite the non-profit Under normal circumstances, the specificity of some projects should be considered while judging the results

of the feasibility studies and project evaluation criteria. Plant production projects generate more returns than other agricultural activities according to the results of this criterion. Adopting the value of the undiscounted profitability index criterion may lead to incorrect investment decisions depending on the type of project considered. The poultry projects showed their ability to achieve returns and profitability for the funds invested in spite of their high investment costs, and that the projects of raising broiler meat is one of the most profitable projects in the sector.

Table 3. Results of the profitability index $(\mathrm{C} / \mathrm{B}$ ratio) criterion

\begin{tabular}{|lcccc|}
\hline Projects & $\begin{array}{c}\text { C/B ratio } \\
\text { discounted } \\
\text { (Loan } \\
\text { financing) }\end{array}$ & $\begin{array}{c}\text { C/B ratio } \\
\text { (Loan } \\
\text { financing) }\end{array}$ & $\begin{array}{c}\text { C/B ratio } \\
\text { discounted } \\
\text { (Self }-\end{array}$ & $\begin{array}{c}\text { C/B ratio } \\
\text { (Self - } \\
\text { financing) }\end{array}$ \\
\hline Feed Factory & 1.125 & 1.132 & 1.109 & 1.139 \\
Poultry hatchery & 1.090 & 1.109 & 1.073 & 1.114 \\
$\begin{array}{l}\text { Production of broiler } \\
\text { chickens }\end{array}$ & 1.113 & 1.153 & 1.082 & 1.167 \\
Production of chicken eggs & 1.022 & 1.071 & 1.004 & 1.074 \\
Farm greenhouses & 1.298 & 1.413 & 1.282 & 1.445 \\
Fish ponds & 1.219 & 1.233 & 1.204 & 1.255 \\
Breeding of milk cows & 1.067 & 1.226 & 0.988 & 1.278 \\
\hline
\end{tabular}

Source: Prepared by the researcher based on the questionnaire data.

The results in Table 4 shows that the NPV values calculated using a discount factor of $10 \%$ in the studied projects were positive, indicating the feasibility of investing in these projects, with the exception of the dairy cattle breeding project, which has a net present value of about - 8,730,905 dinars. The loan contributed to converting the project from economically useless projects into a feasible and economically efficient project as the project was able to achieve returns during its productive life amounting to about 57 million dinars with an increase in the value of the criterion $759 \%$ compared to the case of selffinancing, the highest rate recorded in the projects studied, although the ratio of increases in the standard to the value of the loan did not exceed only $30 \%$. The net present value of the poultry hatchery project amounted to about IQD 1.3 billion, the highest net present value achieved in the studied projects. The loan contributed to raising the value of the standard to about IQD 1.7 billion, an increase of $28 \%$, while the net present value of the egg production project was despite the large volume of investments in the project, which amounted to 3 billion dinars, the highest rate of investment in the studied projects, which accounted for about $35 \%$ of the total investment therein. This loan contributed to raising the value of the standard to about 498 million dinars, an increase of $452 \%$. While the value of the net value of the present value in the greenhouses project amounted to about 608 million dinars, the loan led to an increase in the value of the standard by $13 \%$, which is the lowest recorded rate, while the project of fish ponds has reached the value of about 288 million dinars, then rose to about 339 million IQD with the loan provided for the project. From the above, the economic feasibility of the studied projects can be judged according to the results of the net present value criterion except the milk cattle breeding project. The large volume of investment in various projects is not necessarily evidence of the project's ability to achieve greater returns and benefits, as the large investment costs can be disproportionate to the size of the benefits expected from these projects even with the presence of huge support and loans to these projects. The revenues and benefits of the 
projects depends mainly on the nature of the productive activity and it varies from one project to another. The results of the standard showed different values from the profitability index criterion in some projects, but they were consistent with the feasibility of the projects and they have achieved rewarding returns and benefits. The Net Present Value criterion is one of the international criteria used to evaluate projects, even at the level of international financial institutions. Investments per project and volume of loans granted due to the varying volume of investments in the projects studied and the volume of loans granted, in order to overcome the weakness in the results of the standard, a standard or index of the current value adjusted or the so-called profitability index was calculated table 5 . The studied projects are dealt with on a marginal basis, rather than the total realized return or flows. The invested monetary unit is the common factor among the studied projects. The fish ponds project achieved the largest value of the profitability index, as the value of the index reached about 2.408, which means that the monetary unit invested in the project has achieved a current value of about 1.408 monetary units. This is an indication of the feasibility and profitability of high aquarium projects despite achieving a net present value less than The rest of the projects studied, the loan has contributed to the increase in the present value of returns by 0.433 monetary units, and came in second place feed plant project, where the value of the index adjusted present value of about 2.225 , which means that the monetary unit invested in this project has achieved returns 1.225 units cash. While the feasibility and profitability of other projects studied according to the results of profitability index, as the invested monetary unit achieved losses in those projects, recorded the highest losses in the milk cattle breeding project, where the losses of the monetary unit amounted to about 1.027 monetary units, and loans did not contribute to increase the profitability of monetary unit Invested in these projects. Excluding the greenhouses project, the monetary unit achieved a profit of 0.127 monetary units benefiting from the loan granted. We conclude from the above that relying on a criterion or an indicator is not enough to judge the feasibility of the project and judge the feasibility and efficiency of investment.

Table 4. Results of the net present value (NPV) criterion

\begin{tabular}{|lccc|}
\hline Projects & $\begin{array}{c}\text { NPV } \\
\text { (Self - financing) }\end{array}$ & $\begin{array}{c}\text { NPV } \\
\text { (Loan financing) }\end{array}$ & $\begin{array}{c}\text { Relative } \\
\text { change }\end{array}$ \\
\hline Feed Factory & $\mathbf{1 , 2 4 2 , 7 9 8 , 6 2 8}$ & $\mathbf{1 , 4 9 6 , 6 3 6 , 8 3 5}$ & $\mathbf{2 0 \%}$ \\
$\begin{array}{l}\text { Poultry hatchery } \\
\begin{array}{l}\text { Production of broiler } \\
\text { chickens }\end{array}\end{array}$ & $\mathbf{1 , 3 8 9 , 8 6 0 , 3 6 2}$ & $\mathbf{1 , 7 7 7 , 8 3 1 , 7 5 9}$ & $\mathbf{2 8 \%}$ \\
$\begin{array}{l}\text { Production of chicken } \\
\text { eggs }\end{array}$ & $\mathbf{1 , 0 0 5 , 2 3 6 , 4 5 7}$ & $\mathbf{1 , 5 0 7 , 6 5 3 , 1 6 7}$ & $\mathbf{5 0 \%}$ \\
$\quad$ Farm greenhouses & $\mathbf{9 0 , 3 4 4 , 4 9 5}$ & $\mathbf{4 9 8 , 4 7 8 , 9 1 3}$ & $\mathbf{4 5 2 \%}$ \\
Fish ponds & $\mathbf{6 0 8 , 3 4 9 , 7 2 5}$ & $\mathbf{6 8 7 , 9 3 5 , 9 3 6}$ & $\mathbf{1 3 \%}$ \\
Breeding of milk cows & $\mathbf{2 8 8 , 0 3 4 , 6 0 0}$ & $\mathbf{3 3 9 , 8 4 6 , 0 1 0}$ & $\mathbf{1 8 \%}$ \\
\hline
\end{tabular}

Source: Prepared by the researcher based on the questionnaire data

Table 5. Results of the profitability index (PI) criterion

\begin{tabular}{|lccc|}
\hline Projects & $\begin{array}{c}\text { PI } \\
\text { (Self - financing) }\end{array}$ & $\begin{array}{c}\text { PI } \\
\text { (Loan financing) }\end{array}$ & $\begin{array}{c}\text { Relative } \\
\text { change }\end{array}$ \\
\hline Feed Factory & 2.225 & 2.680 & $21 \%$ \\
Poultry hatchery & 0.781 & 0.9996 & $28 \%$ \\
Production of broiler chickens & 0.436 & 0.655 & $50 \%$ \\
Production of chicken eggs & 0.029 & 0.162 & $414 \%$ \\
Farm greenhouses & 0.997 & 1.127 & $15 \%$ \\
Fish ponds & 2.408 & 2.841 & $17 \%$ \\
Breeding of milk cows & -0.027 & 0.180 & $-641 \%$ \\
\hline
\end{tabular}

Source: Prepared by the researcher based on the questionnaire data 
The results of calculating the internal return criterion for the studied projects. Table 6 showed that the feed plant project achieved the largest internal return for the project, as the value of the criterion reached about $47 \%$, which is higher than the prevailing interest rates. The project has achieved a high internal rate of return of about $45.9 \%$, which shows the ability of the project to achieve internal returns above the prevailing interest rates, so it is necessary to encourage such projects and overcome obstacles Its establishment, perhaps the most important father The constraints faced by these projects are water scarcity and official approvals to be obtained as well as price competition imposed by cage fish projects, all these factors led to the nonproliferation of expected in proportion to the size of the expected returns, has been recorded the value of the criterion calculated with the existence of the loan the highest value In the studied projects, it amounted to about $458 \%$ which is a very high value despite the decrease in the volume of investments in the project, which constitutes only about $1.4 \%$ of the total investments of the projects studied. While the table egg production project was able to achieve an internal rate of return exceeding the discount rate used in discounting cash flows for projects is low, which is $10 \%$, the value of the internal rate of return rate of about $10.6 \%$, which gives an indication that such projects are marginal projects, as achieved an increase in the internal rate of return of about $0.6 \%$ which is not enough to judge the feasibility of the project in light of the price and productivity risks that the project could face, and also did not help the loan to raise the value of the benchmark significantly as the internal rate of return reached about $14 \%$, although the loan to investment costs ratio is around $39 \%$. The results of the standard did not differ significantly in the milk cows project, despite the losses achieved, the results of the standard, are consistent with the results of other discounted standards, where the internal rate of return $9.5 \%$, which is slightly lower than the discount rate used, and is the lowest recorded internal rate of return The project contributed to increase the profitability of the project and thus increased its feasibility, as the value of the standard reached about $16 \%$, which is consistent with the results of the net present value criterion. While the value of the internal rate of return in the project of greenhouses and poultry hatchery project about $31 \%, 27 \%$, respectively, higher than the prevailing interest rates, indicating the feasibility of these projects and their ability to achieve rewarding returns, while the loans granted to raise the value of the standard in the two projects about $48 \%, 52 \%$ respectively.

Table 6. Results of the internal rate of return (IRR) criterion

\begin{tabular}{|lccc|}
\hline Projects & $\begin{array}{c}\text { IRR } \\
\text { (Self - financing) }\end{array}$ & $\begin{array}{c}\text { IRR } \\
\text { (Loan financing) }\end{array}$ & $\begin{array}{c}\text { Relative } \\
\text { change }\end{array}$ \\
\hline Feed Factory & $\mathbf{4 7 \%}$ & $\mathbf{2 9 7 \%}$ & $\mathbf{5 3 2 \%}$ \\
Poultry hatchery & $\mathbf{2 7 \%}$ & $\mathbf{5 2 \%}$ & $\mathbf{9 5 \%}$ \\
Production of broiler chickens & $\mathbf{2 0 \%}$ & $\mathbf{4 0 \%}$ & $\mathbf{1 0 3 \%}$ \\
Production of chicken eggs & $\mathbf{1 0 . 6 \%}$ & $\mathbf{1 4 \%}$ & $\mathbf{3 6 \%}$ \\
Farm greenhouses & $\mathbf{3 1 \%}$ & $\mathbf{4 8 \%}$ & $\mathbf{5 3 \%}$ \\
Fish ponds & $\mathbf{\% 4 5 . 9}$ & $\mathbf{4 5 8 \%}$ & $\mathbf{8 9 8}$ \\
Breeding of milk cows & $\mathbf{9 . 5 \%}$ & $\mathbf{1 6 \%}$ & $\mathbf{7 0 \%}$ \\
\hline
\end{tabular}

\section{Source: Prepared by the researcher based on the questionnaire data}

After reviewing the evaluation criteria, the most important observation that we would like to point out is that no matter how accurate the evaluation results are, they are not in themselves a necessary and sufficient condition for the success of the project and the achievement of the expected results of it, since the poor implementation or management may fail all the advantages inherent in it. Practical experience has often proved that good execution and management of investment projects with modest economic or financial returns is often more feasible than implementing poorly managed investment projects. Based on the results obtained in the light of the results of the criteria applied in the research, the research reached a set of recommendations. The agricultural initiative has a great impact in raising the feasibility of investment in the agricultural sector, and the 
research recommended the need to use the lending funds of the agricultural initiative as a tool to raise the efficiency and feasibility of agricultural projects, which would contribute to the process of agricultural development in Iraq. The need to rely on discounted evaluation criteria to judge the feasibility of projects and no other criteria. Relying on the net cash flow instead of accounting profit in calculating the simple rate of return to ensure the accuracy of the results, as well as relying on the discounted payback period to judge the feasibility of the projects in the studies submitted to obtain financial funding from the Agricultural Bank. Protecting domestic products projects from competing with foreign products in order to allow them to expand production and achieve an economic return to achieve the objectives set for them, and to spread awareness of the importance and role of feasibility studies and evaluation of projects in protecting the funds of investors and donors of agricultural loans.

\section{REFERENCES}

1. Abdul- Karim, A. M., and T. M. Kdawi. 1999. Economic Projects Evaluation-An Analyzing Study of the Feasibility and Efficiency Performance. Second edition. AlKutb Press. Univ. of Mosul. pp:404

2. Ajlouni, M. M. and S.S. Al-Halaq. 2010. Feasibility Studies and Projects Evaluations. Al-Yazori Press. Amman, Jordan. pp:284

3. Al-Issawi, K. J. 2011. Feasibility Studies and Evaluation of Projects .Al-Manahej Press, Amman, Jordan. pp: 127

4. Al-Zuri, R. A. 2003. Evaluating the Performance Efficiency of Mansour State Company for the Period (1989-2001). M.Sc. Thesis. College of Administration and Economics. Baghdad University. pp:151

5. Atrill, Peter. 2000. Financial Management for Non-specialists. $2^{\text {nd }}$. ed. Financial Times Inc. England.pp:112

6. Attia, K. M. 2008. Economic Feasibility Studies. Development Center Graduate Studies and Research, Faculty of Engineering - Cairo University, Egypt. pp:3

7. Avinash , K.1995. The Options Approach to Capital Investment. Harvard Business Review. pp:105-115

8. Barbaz, D. S. 2012. Evaluating the Efficiency of the Performance of Greenhouse
Projects in Karbala. M.Sc. Thesis. Coll. of Agric.,Univ. of Baghdad.pp:176

9. Barbaz, D. S. and J. M. H. Al-Azzi, 2012. The efficiency of performance of greenhouse projects in province of Karbala for the year 2009-2010. The Journal of Iraqi Agricultural Sciences. 43 (4):70-74

10. Barbaz, D. S. 2014. The economic evaluation of producing wheat al-abaichi farm. The Iraqi Journal of Agricultural Sciences. 45 (2): 165-173

11. Barbaz, D., and S. izz aldin. 2019. Role of tenure in the feasibility of wheat production projects in Dhi-Qar governorate. The Iraqi Journal of Agricultural Sciences .50(6).

12. Bodie, Z. , Kane, Alex Marcus and J. Alan, 1999.Investments. $4^{\text {th }}$.ed. Jon Wiley and Sons Inc. USA. pp: 534

13. Donald, J. and W. Malone. 1981. Introduction to Agricultural Economics. MacMillan Publishing Co. pp: 39-55.

14. FAO, 2011. Consolidated Changes to the First Draft of the Voluntary Guidelines on the Responsible Governance of Tenure of Land. Fisheries and forests in in the context of national food security.pp:51

15.

http;//www.amosweb.com,amoswebLLC,2000 2012[accessed; June11, 2012].

16. Issawi, K. J. 2010. Economic Feasibility Studies and Evaluating Projects Theoretical and Practical Analysis. $1^{\text {st }}$ ed. Ammaan Jordan.pp:305

17. Izzi , J. 2000. Maximization profits of productive institution or max. Sales. The Iraqi Journal of Agricultural Sciences. 31 (4): 616630

18. Kay, D. William, M. and A. Partricia,. 2006. Farm Management. 6th ed. McGrwHill. Co. Inc.pp: 57

19. Mashhadani, A. M. and M. Abdul. 2006. Evaluation of financial for The peanut production in the governorate Diyala production season 2003. The Iraqi Journal of Agric. Sci.37 (2).pp:11-22

20. McMenamin, Jim.1999. Financial Management : an Introduction. $1^{\text {st }}$.ed .N.Y. Routledge.pp:366

21. Mousa, N. S. and O. A. Salam. 2011. Feasibility Study of Economy And Evaluate Investment Projects. Massira Press, Amman, Jordan. pp: 334 
22. Najjar, Y. G. 2010. Projects Evaluation Analyzing the Criteria and Indicators of Feasibility Studies, and Evaluating Efficiency of Performance. Djlah Press. Amman, Jordan. pp:393

23. Serguieva, A. and J. Hunter. 2000. Investment Risk Appraisal. pp: 25

24. Shukla, R.1999. Investments. $2^{\text {nd }}$. ed. www.som.syr.edu/facstaff/rkshukla
25. Spinks, Leona.2005. Understanding the Iraqi National Development Strategy.pp:21.

26. Van, H. and C. James, 1998. Financial Management and Policy. 11th.en.N.J.:Prentice - Hall. Inc.pp:143

27. Watson, D. and H. , Antony.1998. Corporate finance Principles and Practice. $1^{\text {st }}$ .ed. Financial Times. England.pp:57. 